\title{
THE ROLE OF IOT IN THE RELATIONSHIP BETWEEN STRATEGIC LOGISTICS MANAGEMENT AND OPERATIONAL PERFORMANCE
}

\author{
YAN M. LOPES ${ }^{1}$ \\ (iD) https://orcid.org/0000-0002-7150-7867 \\ ROBERTO G. MOORI ${ }^{1}$ \\ (iD) https://orcid.org/0000-0001-5690-746X
}

To cite this paper: Lopes, Y. M., \& Moori, R. G. (2021). The role of IoT on the relationship between strategic logistics management and operational performance. Revista de Administração Mackenzie, 22 (3), 1-27. doi:10.1590/1678-6971/eRAMR210032

Submission: Feb. 28, 2020. Acceptance: July 30, 2020.

Mackenzie Presbyterian University (UPM), São Paulo, SP, Brazil.

\section{(cc) BY This is an open-access article distributed under the terms of the Creative Commons Attribution License.}

\footnotetext{
This paper may be copied, distributed, displayed, transmitted or adapted for any purpose, even commercially, if provided, in a clear and explicit way, the name of the journal, the edition, the year and the pages on which the paper was originally published, but not suggesting that RAM endorses paper reuse. This licensing term should be made explicit in cases of reuse or distribution to third parties.

Este artigo pode ser copiado, distribuído, exibido, transmitido ou adaptado para qualquer fim, mesmo que comercial, desde que citados, de forma clara e explí́ita, o nome da revista, a edição, o ano e as páginas nas quais o artigo foi publicado originalmente, mas sem sugerir que a RAM endosse a reutilização do artigo. Esse termo de licenciamento deve ser explicitado para os casos de reutilização ou distribuição para terceiros.
} 


\section{ABSTRACT}

Purpose: Against the backdrop of the transaction costs and theoretical strands of thought in authors of the strategic logistics management (SLM), operational performance (OP), and the internet of things (IoT), the purpose of this study is to verify if the IoT performs a mediating effect on the relationship between SLM and OP.

Originality/value: The bibliometric study indicated that studies on the IoT aimed at the business area are still scarce. Therefore, there is a prospect of expansion of the knowledge frontier of the administration field. This article seeks to show whether the IoT has a mediating influence on the relationship between SLM and OP, in addition to highlighting the most significant variables of each construct. This study can help business managers and researchers to identify the benefits of adopting IoT. Design/method/approach: For that, a quantitative research was carried out. The research collected data through a semi-structured questionnaire with a sample of 76 companies. Data were treated by descriptive statistics and multivariate statistics with the modeling technique in structural equations. Before the application of the modeling technique in structural equations, data were submitted to tests of convergent and discriminant validity.

Findings: The IoT plays a mediating but partial role in the relationship between SLM and OP. Implementing the IoT provides better efficiency by enabling proactive decisions, interconnecting resources, automating, streamlining, remotely controlling, generating customer information, and eliminating errors.

\section{KEYWORDS}

Strategic logistics management. Internet of things. Operational performance. Structural equation modeling. Measurement scale. 


\section{INTRODUCTION}

Logistics is an essential element for commercial activities, as it encourages the exchange of goods between different producing locations. This process of trade follows the principle of comparative advantage, which, in Williamson's (2007) point of view, is relative. Because of that, managers should focus on their costs, especially on transaction costs.

To survive in a competitive market, companies need to offer an increasingly better and more efficient service to their customers. In this context, Strategic Logistics Management (SLM) becomes necessary to generate better results (Bowersox, Bowersox, Closs, \& Cooper, 2014). Logistics management seeks to place products and services at the right time and in the right place, in addition to paying attention to the conditions desired by customers, promoting the company's OP (Ballou, 2006), as well as significantly reducing costs (over 60\%) and increasing profits by more than $75 \%$ (Marquez, Nieto, $\&$ Pardo, 2015). In this sense, SLM can contribute to the OP by improving delivery speed, delivery consistency, flexibility to meet unusual and unexpected customer requests, reducing failures, and increasing availability (Bowersox et al., 2014). In an extremely competitive landscape, Marques (2017) suggested that digital transformation has collaborated for the achievement of the desired performance by companies.

Digital transformation is at the heart of the fourth industrial revolution, which facilitates the interaction between physical and virtual components through technologies such as the internet of things (IoT) and artificial intelligence (AI). There are many discussions about the occurrence of this revolution, but for Schwab (2016), it stands out because everything happens quickly, in depth, and in a way that impacts the whole system. The IoT, an "arm" of this revolution, changes the global value chain, communication, planning, logistics, and production arrangements (Porter \& Heppelmann, 2015). The IoT is a technological resource that has the combination of sensors, connectivity, and mobility as some of its basic characteristics, being important for the digitization of the industry. Currently, IoT applications are varied, permeating almost all activities, such as transportation, construction, agriculture, and healthcare (Patel \& Patel, 2016). A study carried out by the Gartner Group (2017), the world's leader in technology research and consulting, found that, in 2017, 8.4 billion connected devices were used worldwide, representing an increase of $31 \%$ over the number of connected devices in 2016. 
Regarding logistics, the IoT assists managers in several challenges, such as rapid decision-making in real-time based on freight cost, average contract profitability, and on-time delivery rate, in addition to the monitoring of failure events. Realizing that the IoT allows a quick response to an ever-changing scenario, reducing operational deficiencies, such as human error and ill-intentioned activities (Porter \& Heppelmann, 2015), as well as improving overall production efficiency through synergy between processes (Chu, Chen, \& Dang, 2013), this research sought to answer if the application of the IoT mediates the relationship between SLM and OP.

About delimitations, we collected data from Brazilian logistics and retail companies that applied the IoT in the inventory/storage and transportation management processes, once logistic activities are the ones that represent the higher cost (Ballou, 2006).

A bibliometric study was carried out by searching the keywords "logística" (logistics) and "internet of things" in the publications (journal) from Coordination for the Improvement of Higher Education Personnel (Capes), selecting only articles that were peer-reviewed and published in English. It was possible to identify eight articles published between 2013 and March 2018 in business journals. Thus, we concluded that IoT studies are still accommodated in their birthplace, which are the fields of knowledge of computer science and engineering.

This article expands the boundary of knowledge of the application of IoT in the business area; in addition to that, by demonstrating the mediating influence of the IoT, a model was created with the significant variables of each construct, which can be used in future research. This study can also help logistics managers to see the operational results generated by the application of IoT in strategic management.

\section{THEORETICAL REFERENCE AND HYPOTHESES}

\subsection{Strategic logistics management}

The geographical separation between suppliers, companies, and customers has required the construction of an efficient logistics system by companies, essential for trade, as logistics connects production sites to markets separated by time and distance. In this sense, the definition of logistics was described by the Council of Logistics Management (CLM) as "the process of planning, implementing and controlling the efficient, effective flow and 
storage of goods, services, and related information from the point of origin to the point of consumption for conforming to customer requirements" and its management makes it necessary to guide activities to predefined functional strategies and to control trade-offs, such as cost and value to the customer (Prasad \& Singh, 2015; Marquez et al., 2015). According to Ballou (2006), logistics is strategic because it is intertwined with the general corporate strategy so that the corporation defines a strategy and logistics performs its functional strategic plan based on this guideline. Bowersox et al. (2014) mentioned the network of facilities, order processing, transport, inventory, and storage as the main logistics activities, but it was possible to conclude, in the case study carried out by Marquez et al. (2015), that the most important were: transportation, commercial and separation of products (tied to storage).

Inventory/warehouse management is considered a challenge for logistics managers because variations in the demand for finished products constantly occur, which leads to higher storage costs. The objective is always to provide faster, more objective, and safer decision-making (Saurin, Raupp, \& Trento, 2014) based on the objectives defined by the organizations. For Martello and Dandaro (2015), warehouse management consists of planning how to control the materials within the organization, to maintain a balance between inventory and consumption, which is necessary due to the need to control inputs from purchases. For Ballou (2006), it consists of: 1. input of the product; 2 . warehousing; 3 . management of inventory levels; 4 . processing of orders and withdrawal of the merchandise; and 5. preparation of the shipment.

Transportation is the area of logistics that geographically moves and positions inventory. Therefore, due to this importance, large and small companies allocate managers as responsible for their activities (Bowersox et al., 2014). According to Ballou (2006), transport management is concentrated in: 1 . modal selection; 2 . freight consolidation; 3 . routing and scheduling of shipments; 4 . complaints processing; and 5 . shipment tracking.

\subsection{Internet of things}

The IoT rests on the idea of managing processes through connectivity, mobility, and analysis of data generated by sensors, bringing the real world closer to the virtual (Abersfelder, Bogner, Heyder, \& Franke, 2016). The concept of IoT was promulgated by Ashton (2009) at the Massachusetts Institute of Technology (MIT), who predicted the connection of physical 
objects to the internet by means of sensors, such as Radiofrequency identification (RFID) which allows the gathering of information without human interference. For Pathak (2016), the term was related to the extent of connectivity through sensors for data collection, analysis, and management, i.e., it was an interconnected environment of objects that can communicate with one another. For Presser and Gluhak (2009), the IoT consisted of a combination of technologies such as RFID, wireless networks, and wireless sensors. IoT was derived from a things-oriented perspective, which was beyond RFID because the latter was just a tag that allows the identification or tracking of an object (Nassar \& Horn, 2014). In this sense, the IoT is a combination of several technologies, which allows not only the simple identification of objects but also the accomplishment of daily tasks from intense use of smartphones, laptops, GPS, and networks.

\subsection{Operational performance}

The OP is fully related to supply chain and logistics management capacity, and it is an indicator of competitive advantage (Bowersox et al., 2014). In this way, its evaluation is indispensable for a company that intends to remain in the market, as it controls the operational activities, identifies problems that need the interference of the managers, provides feedback to guide planning, among other functions. This evaluation is common in companies' daily routines, but it is not a simple task since it is necessary to establish what is intended to be measured and establish adequate parameters that evaluate what one wants to measure (Paiva et al., 2014). Regarding the importance of performance indicators, Bititci (2015) portrayed that they are used to measure how well the company is evolving in relation to its goals and targets set in strategic planning and creating favorable conditions for the elimination of wastage.

The OP is a multidimensional construct composed of various operational aspects, such as cost, flexibility, and quality, and it can be compared to the effectiveness of the requirements of the clients and to the efficiency of the activities (Duong \& Paché, 2015). For Ballou (2006), considering the many dimensions of customer service, finding a measurement that was sufficiently comprehensive to ensure effective performance evaluation is not a simple task.

The performance measures mentioned by Bowersox et al. (2014) that fit the operational process are cost, customer service, productivity, and quality. Complementarily, Rodrigues, Lynch, and Stank (2004) employed six multi- 
dimensional indicators to evaluate logistics performance: cost, delivery time, delivery reliability, order comprehension capability, inventory turnover, and customer satisfaction. The authors also concluded that the logistics manager seems to have difficulty in dealing with "real-time delivery confirmation" and with the "high rate of return of goods", making it limited to serve different customers, recipients, and regions.

\subsection{Conceptual model and hypotheses}

Considering the diversity of possibilities of applying IoT in business, this study sought to understand how this technology can be used to mediate the relationship between SLM and OP. In addition, revenues were inserted into the model as a control variable in order to verify whether companies with higher or lower revenues presented different results because, based on the theoretical reference, the application of the IoT requires that the company invest a considerable value in sensors, (Yu \& Bai, 2013). Evdokimov et al. (2019) created a pricing model for IoT projects and observed that the IoT generates several benefits to the organizations, and this makes a company with high revenue have a greater chance of implementing an IoT project. So, the control variable "revenue" was inserted in the model to examine this force (Tu, 2018; Brous, Janssen, \& Herder, 2019). The base model, therefore, is represented in Figure 2.4.1.

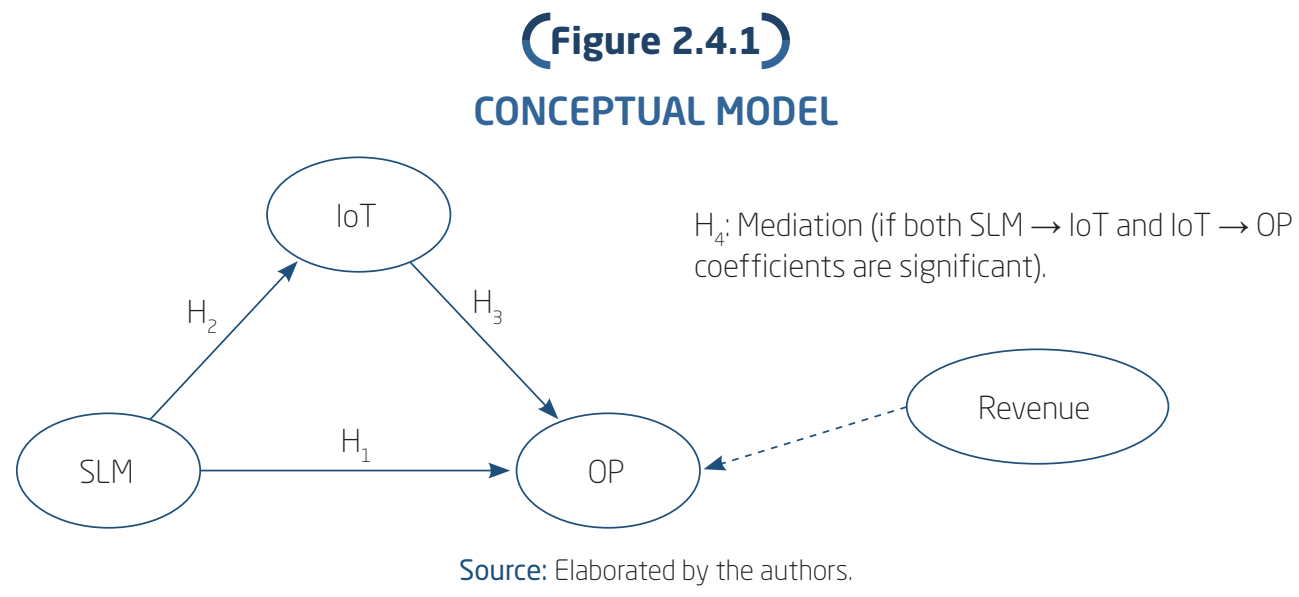

Based on the theoretical framework of this research, it was identified that SLM is composed of decisions made to obtain a greater OP, and that is divided into short, medium, and long term. However, OP may not be 
achieved in its entirety, affected, for example, by the exaggerated mismatch in the trade-off between cost and better customer experience - the pursuit of low cost may lead the company to offer a poor-quality service (Bowersox et al., 2014). Macaulay, Buckalew, and Chung (2015) found that logistics management requires more transparency, integrity control, detailed shipment tracking, and constant optimization of assets to generate OP. Transportation management has always been a point of attention for managers because it directly impacts productivity, safety, and operational costs (Machline, 2011). Kazimírová, Busa, and Puskás (2015) complemented the functions of the manager, who always seeks to reduce expenses with fuel and maintenance of vehicles, as well as to offer a quality service to customers because the activity was classified as one of the largest in logistics costs and represented a significant part of the sales price of the products, then the activities should be optimized in order to improve vehicle utilization, achieve higher levels of customer service, and other benefits (Ting \& Liao, 2013; Hübl, Altendorfer, $\&$ Jodlbauer, 2013). Considering that the strategy is a performance antecedent, the following hypothesis was developed:

- $\mathrm{H}_{1}$ : SLM has a positive effect on OP.

The application of technologies in the SLM has occurred because transportation and storage processes affect the costs and the quality of the service provided. Thus, intelligent logistics (logistics with IoT) is applied to the management processes so that it is able to imitate human intelligence, perception, learning, reasoning, and autonomous problem-solution (Yu \& Bai, 2013). In addition, by combining data with the remote-control capability, it is possible to create optimization opportunities for logistics activities (Porter \& Heppelmann, 2015). In the transport of goods, for example, sensors can be coupled to the vehicles so that sellers or dealers can be aware of their location - they can estimate the arrival time of the merchandise to plan their sales (Zhang, He, \& Xiao, 2013). The IoT consists not only of sensors that allow wireless communication but also of autonomous and proactive behaviors, results of information sharing that allow object traceability, monitoring, and automated management (Nassar \& Horn, 2014; Chu et al., 2013; Zhang et al., 2013). Thus, the IoT offers the capability to provide (more) timely information for decision making and lesser response times, automation of decision-making, and improved planning, due to insights created by higher volumes of data (Brous et al., 2019). Considering these facts, the following hypothesis was developed:

- $\mathrm{H}_{2}$ : SLM has a positive effect on the application of the IoT. 
Giudice (2016) stated that the IoT enabled OP because it provides refined real-world information, streamlining the business management process. Macaulay et al. (2015) stated that the logistics and the IoT are a perfect match since technology connected several assets corresponding to the logistical flow and enables the analysis of data generated from these connections in order to capture new ideas to achieve higher levels of OP. Porter and Heppelmann (2015) stated that the IoT consists of information processing to act and react in order to maximize performance. In an expansion of the production scale, which requires rapid growth in demand and storage management, the IoT strengthens inventory control, reduces logistics and distribution costs, and optimizes the purchasing process (Yu \& Bai, 2013). Porter and Heppelmann (2015) contributed significantly by demonstrating the relationship along a supply chain prior to the application of the IoT - companies had to obtain the information by verifying orders issued, submitting satisfaction and intention questionnaires to customers, and by visiting suppliers. Brous et al. (2019) said that IoT allows for the reduction of operating costs, generates insights into new forms of revenue, and increases efficiency in communicating with the customer. Considering these facts, the following hypothesis was developed:

- $\mathrm{H}_{3}$ : The application of the IoT has a positive effect on OP.

Porter and Heppelmann (2015) stated that the data generated through sensors are valuable, whose value increases exponentially when integrated with other data, such as service history, inventory locations, traffic patterns, and others. As for IoT applications in logistics (internet of smart logistical - IoSL), it is possible to increase synergy with all logistics activities-sensors deployed in well-defined objectives; and sending information to intelligent software can reduce inventory, shorten customer response and improve overall production efficiency (Zhang et al., 2013). Galegale, Silva, Siqueira e Souza (2016, p. 437) contributed by suggesting that the application allowed a "greater and more rapid adaptation to the changes in the environment, as well as greater agility in the decision making"- the application of sensors that communicate with systems and equipment enhances the quality and information for all logistical activities, which enables diverse applications, such as production traceability. The use of sensors can impact improvements in readiness, speed, flexibility, reduction of inventory costs, and increase in the quality of products and services (Bowersox et al., 2014). Tu (2018), in his research, mentioned that IoT brings some benefits, such as reducing the complexity of supply chain integration, detailed product life 
cycle information, an improvement on the tracking system, and access to product information. Hopkins and Hawking (2018) raised in their research that the application of IoT in transportation allowed to better understand and improve driving behaviors, in addition to monitoring live sensor data from the company vehicle fleet, capturing speed, location, braking data, and engine, to develop future training programs. Considering these facts, the following hypothesis was developed:

- $\mathrm{H}_{4}$ : The application of the IoT mediates the relationship between SLM and OP.

\section{METHODOLOGICAL PROCEDURES}

\subsection{Nature and type of research, collection instrument, sample, and research subjects}

This study was considered of a descriptive nature of the quantitative type (Creswell, 2010), in which the degree of mediation of the IoT construct was verified in the relationship between SLM and OP. For this purpose, a questionnaire composed of objective statements segmented into four blocks was employed: 1. demographic data (company turnover, number of employees, and others); 2. ten assertions of the SLM construct; 3. ten assertions of the IoT construct; and 4. ten assertions of the PO construct. In the last three groups, respondents were asked to mark with an "X", in the degree of agreement or disagreement, on a scale of 1 (SD = strongly disagree) to 6 (SA = strongly agree). The questionnaires were validated through a pre-test with a sample of three logistic managers (defined by convenience); thus, it was possible to identify and eliminate problems regarding the understanding of the questions, the format, and the relevance of the affirmations in relation to the constructs. After validation, the questionnaire was sent via electronic form to 7,940 companies. The sample size was defined based on the software $\mathrm{G}^{*}$ Power 3.1.9. For the calculation, the power of $0.80, \mathrm{f}^{2}$ median $=$ 0.15 , and two predictors were used since the OP construct received two arrows (Hair, Anderson, Babin, Black, \& Tatham, 2005). The minimum sample calculated was 68 cases. The effective sample size of the present study was 76 respondents. However, it is known that the sample size is controversial in multivariate analyzes. From a conceptual point of view, Hair et al. (2005) argue as a general rule that there are five observations for each inde- 
pendent variable, and preferably the sample size must be greater than or equal to 100; however, some researchers propose a minimum of 20 cases. From a statistical point of view, Hair et al. (2005) say that, specifically for the application of the factorial analysis technique, the researcher must ensure that: a) data matrix has sufficient correlations, which can be verified by the Bartlett test of sphericity, or by the measure of sampling adequacy (MSA), in which it is possible to quantify the degree of inter-correlations between variables and the adequacy of factor analysis. However, the researcher can employ the concept of statistical test power to specify factor loads considered significant for different sample sizes. Thus, for a statistical test power of $80 \%$, a significance level of 0.05 , and proposed inflation of standard errors of factorial loads, Hair et al. (2005, p. 107) suggest a sample size greater than or equal to 70 respondents, for a factorial load greater than or equal to 0.70 and test power of $80 \%$.

After defining the questionnaire, companies related to logistics management that use the IoT technology applied to managers (directors, managers, supervisors, and coordinators) were selected.

\subsection{Data treatment and method limitations}

The data were treated by descriptive statistics (mean, standard deviation, and coefficient of variation) and multivariate statistics (modeling in structural equations). Descriptive statistics allowed us to examine the data collected (such as missing data), identify unusual observations, data entry errors, or omission of responses. Structural equation modeling allowed a simultaneous assessment of several different related equations (Hair et al., 2005). Before the application of the modeling technique in structural equations, the data were submitted to measurements and scales validation through convergent validity tests, Cronbach's Alpha, composite reliability (CR), and discriminant validity. To validate the structural adjustment, the determination coefficient $\left(\mathrm{R}^{2}\right)$ was used, complemented by the statistics $\mathrm{Q}^{2}$ (predictive validity) and $\mathrm{f}^{2}$ (effect size). To estimate the structural relationships of the model, as well as to verify the statistical significance, we used the PLS-PM method (partial least squares - path method), which is considered the most suitable for studies that present an absence of symmetric distributions of the measured variables or a sample of insufficient size to estimate the model (Ringle, Bido, \& Silva, 2014). Finally, to typify IoT mediation in the relationship between SLM and OP, whether partial, total, or nonexistent, the Sobel test was used (Baron \& Kenny, 1986). 
The main limitation was the sample size that can lead to the use of statistical inferences (Creswell, 2010). However, this research explored a recent and little-known topic in companies, a fact confirmed in the messages sent by the interviewees during the data collection phase of the questionnaires: they reported that they did not apply the IoT, when, in fact, they applied (which was evidenced in questions about their logistical processes), and who knew what it was, when, in fact, they did not.

\section{DATA PRESENTATION}

Data were collected in the second half of 2018. 7,940 questionnaires were sent to the companies by e-mail. Of the total questionnaires responded, $76(0.96 \%)$ were considered fit for the research, or $0.96 \%$ of the total sent.

\subsection{Companies and respondents' profile in the sample}

As for the profile of the companies, they represent the industries of transport (42\%), transport and storage $(30 \%)$, storage $(9 \%)$, and the rest (19\%) are up to hybrid sectors such as retail, retail and storage, and storage and transport.

Regarding the profile of the interviewees, the majority were executives or held a managerial position (65.58\%), and $60.53 \%$ had revenues less than or equal to R \$ 90.0 million. Since they had been using the IoT, $55.26 \%$ had been using the technology for more than three years; $23,68 \%$ had been using it between one and three years, and $21.05 \%$ for less than one year.

\subsection{Validation of measurement and scales of the model of measurement}

Initially, the data collected were examined by descriptive statistics (mean, standard deviation, and analysis of covariance) to identify atypical observations or extreme responses that could influence multivariate analysis. The average values obtained were on the concordant side of the measurement scale, with standard deviations less than 1 and coefficients of variation less than 0.20, i.e., considered as average (Gomes, 1985).

After this phase, the data were subjected to factorial analysis to look for mistakes, validate and define the underlying structure of the data matrix. In this phase, the data matrix proved to be suitable for the application of factorial analysis with an MSA/KMO equal to 0.877 and a significant Bartlett's Test 
of Sphericity ( $p$-value $=0.000$ ). To obtain this result, four measures were discarded because they had low load factors (less than 0.7), two measures from the SLM construct, one from the IoT construct, and one measure from the OP construct. Thus, of a total of 30 measures, 26 measures remained, that is, eight measures for the SLM construct, nine for IOI, and nine measures for the OP construct.

Once the initial structure of the model was identified, statistical validation was resumed. The first aspect analyzed was the convergent validity, obtained by observing the average variance extracted (AVE). It represented the total of data explained by each latent variable $(\mathrm{LV})$, their respective sets of measurement variables, or how much, on average, the variables correlated positively with their respective constructs. In this case, to obtain a satisfactory result, they must be greater than 0.50 (Chin, 1998; Fornell \& Larcker, 1981).

After the analysis of the AVE, the values of internal consistency, the Cronbach's alpha coefficient, were analyzed based on the inter-correlations between variables. It is worth mentioning that this coefficient is sensitive to the number of variables observed. Regarding the reference values for this analysis, values above 0.6 and 0.7 can be considered adequate for exploratory and descriptive research, respectively (Hair, Hult, Ringle, \& Sarstedt, 2014). Simultaneously, it was possible to evaluate the model's Composite Reliability (CR), which, according to Ringle et al. (2014), is more suitable for PLS-PM, as it prioritizes variables according to their reliability without considering the number of variables observed for each construct. The reference values for admitting that the variables are satisfactory are 0.70 and 0.90 . However, both cases (Cronbach's alpha and CR) assessed whether the sample was free of bias, that is, whether the responses were reliable.

The analysis shown in Figure 4.2.1 shows that all constructs had an AVE value $>0.60$. The Cronbach's alpha of these variables was also greater than 0.90, as well as the CR, which was also greater than the minimum of 0.90. After validating the relationship between the observed variables (OVs) and the respective latent variables $(\mathrm{LV})$, it was necessary to verify the independence of the LVs, i.e., to verify whether the measurement variables had a greater relationship with their construct than with others. One of the ways to confirm discriminant validity is through cross-loading - in this case, the indicators needed to be higher in their respective VE (Chin, 1998). For calculation purposes, SmartPLS recalculated the factorial loads of each OV in all LVs of the structural model (Ringle et al., 2014). As a result, all variables showed a greater correlation with their respective constructs. 
The criterion of Fornell and Larcker (1981) was also used to effect discriminant validity. In this case, the square roots of the AVE values for each construct were compared with Pearson's correlations between latent variables - the square roots must be greater than the correlations presented (Bido, Godoy, Araujo, \& Louback, 2010). Figure 4.2.1 shows results, by construct, of descriptive statistics, bi-varied correlation, number of original purified measurements, Cronbach's alpha, AVE, CR, and AVE square root.

\section{(Figure 4.2.1)}

DESCRIPTIVE STATISTICS, BIVARIATE CORRELATION, AND VALIDATION INDEXES

\begin{tabular}{lllllll}
\hline \multirow{2}{*}{ Constructs } & \multicolumn{3}{c}{ Descriptive statistic } & \multicolumn{3}{c}{ Bivariate correlation } \\
\cline { 2 - 7 } & Mean & $\begin{array}{c}\text { Standard } \\
\text { deviation }\end{array}$ & Coef. variation & SLM & IoT & OP \\
\hline SLM & 4.74 & 0.913 & 0.193 & 0.78 & - & - \\
\hline loT & 4.25 & 0.819 & 0.193 & $0.55^{\star \star}$ & 0.79 & - \\
\hline OP & 4.73 & 0.839 & 0.177 & $0.72^{\star \star}$ & $0.66^{\star \star}$ & 0.81 \\
\hline Quantity of original measures & & $\rightarrow$ & 10 & 10 & 10 \\
\hline Quantity of purified final measurements & $\rightarrow$ & 8 & 9 & 9 \\
\hline Cronbach's alpha & & $\rightarrow$ & 0.91 & 0.92 & 0.93 \\
\hline Average variance extracted & & $\rightarrow$ & 0.62 & 0.63 & 0.65 \\
\hline Composite reliability & & & 0.93 & 0.94 & 0.94 \\
\hline
\end{tabular}

** Significance for $\alpha \leq 0.01$.

Figure 4.2.2 shows the factorial loads of the observed variables in which the factor loads (greater than 0.7) can be seen by measurements in their respective constructs; it also shows the means (on the concordant side of the scale), standard deviation (minimum 0.871 and maximum of 1.327) and variation coefficient (minimum of 0.18 and maximum of 0.30 ), denoting that the data have an average dispersion and within the acceptable range. 


\section{(Figure 4.2.2)}

FACTOR LOADINGS, DESCRIPTIVE STATISTICS AND INDEX OF ADEQUACY TO THE APPLICATION OF THE FACTOR ANALYSIS TECHNIQUE

\begin{tabular}{cccccc}
\hline & \multicolumn{3}{c}{ Factor loadings } & \multicolumn{2}{c}{ Descriptive statistics } \\
\cline { 2 - 4 } Constructs/variables/description & SLM & IOT & OP & Mean $\begin{array}{c}\text { Std. } \\
\text { deviation }\end{array} \begin{array}{c}\text { Coef. } \\
\text { variation }\end{array}$ \\
\hline
\end{tabular}

My company performs strategic logistics management...

\begin{tabular}{|c|c|c|c|c|c|c|c|}
\hline SLMI & Based in strategic planning & 0.76 & 0.49 & 0.56 & 4.67 & 1.193 & 0.26 \\
\hline SLM2 & As management systems. & 0.80 & 0.43 & 0.47 & 4.55 & 1.182 & 0.26 \\
\hline SLM3 & Integrated among all the company areas & 0.76 & 0.44 & 0.47 & 4.54 & 1.194 & 0.26 \\
\hline SLM4 & With distribution planning. & 0.82 & 0.45 & 0.61 & 4.80 & 1.083 & 0.23 \\
\hline SLM5 & With quality inspection. & 0.76 & 0.47 & 0.54 & 4.63 & 1.231 & 0.27 \\
\hline SLM6 & With flexibility. & 0.76 & 0.50 & 0.56 & 4.71 & 1.175 & 0.25 \\
\hline SLM7 & With discipline. & 0.83 & 0.36 & 0.66 & 4.72 & 1.239 & 0.26 \\
\hline SLM8 & With Focus on the necessities of clients. & 0.78 & 0.29 & 0.60 & 5.26 & 1.012 & 0.19 \\
\hline
\end{tabular}

My company uses the internet of things in the logistics process and it ...

\begin{tabular}{|c|c|c|c|c|c|c|c|}
\hline loT1 & Supports the decision taken. & 0.42 & 0.74 & 0.47 & 4.84 & 1.108 & 0.23 \\
\hline loT2 & Identifies fails before it occurs (proactive). & 0.27 & 0.77 & 0.52 & 4.39 & 1.327 & 0.30 \\
\hline I0T3 & Interchanges resources. & 0.48 & 0.88 & 0.60 & 4.79 & 1.181 & 0.25 \\
\hline loT4 & Allows monitoring activities. & 0.54 & 0.89 & 0.54 & 5.13 & 1.024 & 0.20 \\
\hline loT5 & Allows to automate the management & 0.52 & 0.85 & 0.51 & 4.93 & 1.075 & 0.22 \\
\hline loT6 & Adjusts for change in routine (dynamic). & 0.43 & 0.74 & 0.55 & 4.33 & 1.171 & 0.27 \\
\hline loT7 & Allows control of the activities remotely. & 0.47 & 0.78 & 0.44 & 4.71 & 1.242 & 0.26 \\
\hline ІоТ8 & Generates information to clients & 0.35 & 0.73 & 0.43 & 5.08 & 1.080 & 0.21 \\
\hline loT9 & Eliminates the errors from employees. & 0.37 & 0.73 & 0.58 & 4.49 & 1.183 & 0.26 \\
\hline
\end{tabular}

巳 My company presents in the last two years, related to logistic operational performance...

\begin{tabular}{|c|c|c|c|c|c|c|c|}
\hline $\mathrm{OP1}$ & More efficiency in the process execution. & 0.55 & 0.55 & 0.72 & 4.51 & 1.101 & 0.24 \\
\hline $\mathrm{OP2}$ & Low complaint index. & 0.50 & 0.40 & 0.77 & 4.59 & 1.246 & 0.27 \\
\hline OP3 & Low fail process index. & 0.49 & 0.41 & 0.77 & 4.32 & 1.134 & 0.26 \\
\hline OP4 & Improvement in delivery service quality. & 0.69 & 0.57 & 0.87 & 4.96 & 0.871 & 0.18 \\
\hline
\end{tabular}




\section{(Figure 4.2 .2 (conclusion))}

FACTOR LOADINGS, DESCRIPTIVE STATISTICS AND INDEX OF ADEQUACY TO THE APPLICATION OF THE FACTOR ANALYSIS TECHNIQUE

\begin{tabular}{|c|c|c|c|c|c|c|c|c|}
\hline & & \multirow[b]{2}{*}{ Constructs/variables/description } & \multicolumn{3}{|c|}{ Factor loadings } & \multicolumn{3}{|c|}{ Descriptive statistics } \\
\hline & & & SLM & loT & $\mathrm{OP}$ & Mean & $\begin{array}{c}\text { Std. } \\
\text { deviation }\end{array}$ & $\begin{array}{l}\text { Coef. } \\
\text { variation }\end{array}$ \\
\hline \multirow{5}{*}{ 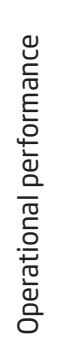 } & OP5 & $\begin{array}{l}\text { Improvement in delivery attendance } \\
\text { flexibility. }\end{array}$ & 0.57 & 0.57 & 0.80 & 4.76 & 1.069 & 0.22 \\
\hline & OP6 & Improvement in logistic process agility. & 0.64 & 0.51 & 0.84 & 4.92 & 1.043 & 0.21 \\
\hline & OP7 & Higher index in delivery service deadline. & 0.56 & 0.58 & 0.82 & 4.99 & 0.916 & 0.18 \\
\hline & OP8 & Higher index in demand attendance. & 0.57 & 0.62 & 0.84 & 4.87 & 0.971 & 0.20 \\
\hline & OP9 & Higher index in resource productivity. & 0.58 & 0.51 & 0.81 & 4.66 & 1.040 & 0.22 \\
\hline
\end{tabular}

Kaiser-Meyer-Olkin measure of sampling adequacy $=0.877$.

Bartlett's test of sphericity: approx. chi-square = 1566.986; $\mathrm{df}=325 ; \mathrm{Sig} .=0.000$. The assertions were measured by the Discordance/Concordance scale, with 6 degrees of importance ranging from totally disagree $(T D=1)$ to totally agree $(T A=6)$

Source: Elaborated by the authors.

After validating the measures and scales of each construct, the statistical significances and adjustments of the measurement model were analyzed.

\subsection{Evaluation of the structural relations of the measurement model}

The results of the application SmartPL3.0, the PLS-PM technique, and the bootstrap for a sample of 76 respondents and 5,000 repetitions are shown in Figure 4.3.1 and were used to evaluate the statistical significance of structural relationships and the adjustment of the measurement model. 


\section{(Figure 4.3.1)}

\section{STRUCTURAL MODEL-CONTROL AND MEDIATION VARIABLES}

a) Without control and without mediation

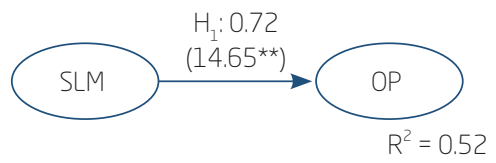

b) Without control and with mediation

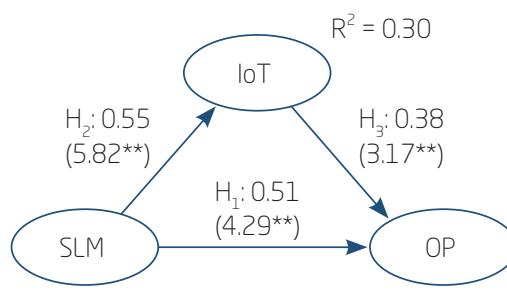

c) With control and without mediation

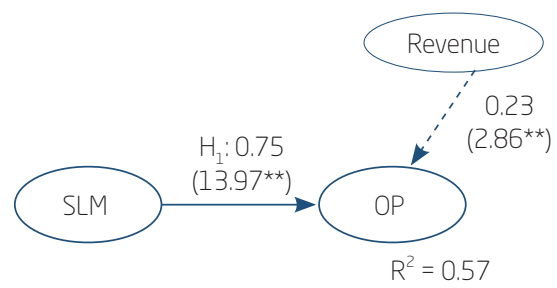

d) With control and with mediation

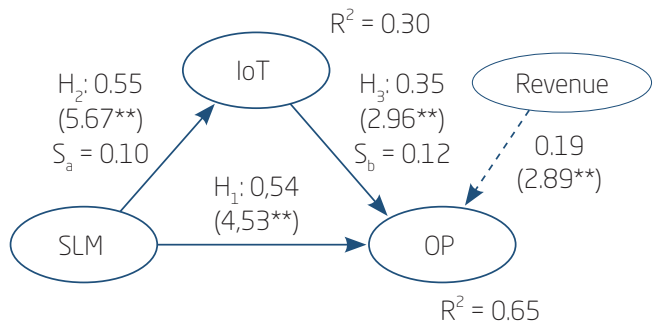

** Significance for $\alpha \leq 0.01 ; S_{a}=S_{b}=$ standard error; (t statistics) in the parentheses.

\section{Source: Elaborated by the authors}

To verify the behavior of the mediating variable (IoT) in the relationship between SLM and OP, the measurement model was examined: 1. without the presence of the control variable and without the presence of the IoT (Figure 4.3.1a); 2. without the presence of the control variable and with the presence of the IoT (Figure 4.3.1b); 3. with the presence of the control variable and without the presence of the IoT (Figure 4.3.1c); and 4. with the presence of the control variable and with the presence of the IoT (Figure 4.3.1d). In the case of the measurement model without the presence of the control variable (figures 4.3.1a and 4.3.1b), SLM influenced OP in $0.72(\mathrm{t}=$ $14.65^{* *}$ ) (Figure 4.3.1a). However, when submitted to the IoT, the effect of SLM on OP decreased to $0.51\left(t=4.29^{* *}\right)$, thus, denoting the influence of IoT as a mediating variable in the relationship between SLM and OP. Still, it is possible to verify that, in the absence of the mediating variable, the control variable reduced the resistance to the impact of the SLM in OP by $4.64 \%[((14.65-13.97) / 14.65)=0.464]$.

We proceeded to verify the behavior of the mediating variable (IoT) in the relationship between SLM and OP, in the presence of revenue as a control 
variable, according to the models shown in Figure 4.3.1c (without the presence of the IoT) and in Figure 4.3.1d (with the presence of the IoT).

In the model shown in Figure 4.3.1c, SLM influenced OP in $0.75(t=$ $13.97^{* *}$ ) and supported the $\mathrm{H}_{1}$ hypothesis. In the model shown in Figure 4.3.1d, the hypothesis tests are represented by the structural coefficients; between parentheses, there are the t-statistic values of the relationships $[\mathrm{SLM} \rightarrow \mathrm{OP}],[\mathrm{SLM} \rightarrow \mathrm{IoT}]$, and [IoT $\rightarrow \mathrm{OP}]$. Also, the standard errors of the relationships [SLM $\rightarrow$ IoT] and [IoT $\rightarrow$ OP] are represented.

The SLM construct had a direct effect on OP with a structural coefficient of $0.54\left(t=4.53^{* *}\right)$ and supported the $\mathrm{H} 1$ hypothesis. The indirect effect was equal to $0.19[0.55 * 0.35=0.19]$. The total effect was equal to 0.73 $[0.54+0.55 * 0.35=0.73]$. The proportion of IoT mediation in the OP variance explained, directly and indirectly, by the SLM, wgich was $26.3 \%$ $\left[\left(0.55^{*} 0.35\right) /\left(\left(0.55^{*} 0.35\right) /\left(\left(0.55^{*} 0.35\right)+0.54\right)=0.263\right]\right.$. The SLM construct had a direct effect on the IoT with a structural coefficient, equal to $0.55\left(\mathrm{t}=5.67^{* *}\right)$ and supported the hypothesis $\mathrm{H}_{2}$, which in turn influenced the OP with a structural coefficient equal to $0.35\left(\mathrm{t}=2.96^{* *}\right)$ and supported hypothesis $\mathrm{H} 3$.

The model also showed that the mediating variable, even with the control variable, continued to have a partial effect since all the relationships had a t-value greater than $2.56(\alpha \leq 0.01)$. As for the relationship between the SLM and OP variables, the impact of the introduction of the IoT, comparing the two models (Figure 4.3.1c and Figure 4.3.1d), a reduction of $65.4 \%$ $[(13.97-4.53) /(13.97) * 100=65.4 \%)$ is shown, which led to the evidence that the mediator variable had an effect on the relationship between SLM and OP, thus, supporting hypothesis $\mathrm{H} 4$.

Once the hypothesis tests $\left(\mathrm{H}_{1}, \mathrm{H}_{2}\right.$, and $\left.\mathrm{H}_{3}\right)$ are statistically significant at level $(\alpha \leq 0.01)$, in addition to reducing the influence of the IoT in the relationship between SLM and OP, and thus highlighting the mediating effect of the use of IoT in the relationship between SLM and OP, we continued to typify this effect, i.e., whether it was partial or total. For that, we used the Sobel test (Baron \& Kenny, 1986) to make a comparison between the strength of the indirect effect of the independent variable in the dependent variable, in which the null hypothesis is the effect equal to zero, given by $t_{\text {sobel }}=\frac{a \times b}{\sqrt{b^{2} S_{a}^{2}+a^{2} S_{b}^{2}}}$, in which the letter "a" refers to the path coefficient between the independent variable (SLM) and the mediating variable (IoT); and " $b$ " refers to the path coefficient between the mediator and the dependent 
variable (OP). Finally, "Sa" and "Sb" are the standard errors of the respective path coefficients. In this case, the following values were assumed: (a): 0.55, $(\mathrm{Sa}): 0.10,(\mathrm{~b}): 0.35$, and $(\mathrm{Sb}): 0.12$. The reference value for $z$ is \pm 1.96 to reject the hypothesis that the effect is null. The result for the model in question was $z=2.58$, which proved the significance of mediation in the proposed final model (Baron \& Kenny, 1986; Iacobucci, Deng, \& Saldanha, 2007). In other words, the application of IoT confirmed the reduction of the direct influence of SLM on OP, thus supporting the H4 hypothesis of the research.

As for the adequacy of the structuring model, the first analysis was the determination coefficient $\left(\mathrm{R}^{2}\right)$. Cohen (1988) defined that, for the field of social and behavioral sciences, an $\mathrm{R}^{2}$ of $2 \%$ is classified as a small effect, an $\mathrm{R}^{2}$ of $13 \%$ as a medium effect, and an $\mathrm{R}^{2}$ of $26 \%$ as a large effect. The adequacy test $\left(\mathrm{R}^{2}\right)$ was applied to the model that did not consider it and to the model that considered the control variable (Revenue) to verify its effect. The adequacy of the model was satisfied in both cases, whose values obtained were R2 = 0.52 and the average of $0.46[0.30+0.61 / 2=0.46]$, denoting a large effect.

In addition, two other indicators of goodness of fit of the model were evaluated: relevance or predictive validity $\left(\mathrm{Q}^{2}\right)$ or Stone-Geisser indicator and effect size $\left(\mathrm{f}^{2}\right)$ or Cohen indicator. The reference value of $\mathrm{Q}^{2}$ must be greater than zero and $f^{2}: 0.02,0.15$, and 0.35 , considered to be small, medium, and large effect sizes, respectively (Hair et al., 2014). The results are shown in Figure 4.3.2:

(Figure 4.3.2)

MODEL ADJUSTMENT: PREDICTIVE VALIDITY AND EFFECT SIZE

\begin{tabular}{ccc}
\hline Constructs & $\mathrm{Q}^{2}$ & $\mathrm{f}^{2}$ \\
\hline SLM & - & 0.45 \\
\hline IOT & 0.16 & 0.50 \\
\hline OP & 0.35 & 0.50 \\
\hline
\end{tabular}

Source: Elaborated by the authors

Therefore, the estimation data of the measurement model had an excellent predictive capacity $\left(\mathrm{Q}_{2}\right)$, and the $\mathrm{f}^{2}$ indicator demonstrated that all variables have a highly representative effect on the model. 


\subsection{Research results}

Research has shown that the use of the IoT plays a mediating role in the relationship between SLM and OP. In addition, the estimation of the measurement model made it possible to verify the impact of the "Revenue" control variable, perceived because there was a significant increase in the adjustment of the model $\left(\mathrm{R}^{2}\right)$ when included in the model. The result indicated that companies with higher revenues are more likely to apply IoT because it requires a high investment in technological structures and people training (Yu \& Bai, 2013; Evdokimov et al., 2019). Considering the general objective of this research, which is to verify the mediating influence of the application of IoT between SLM and OP in the areas of transport and storage of logistics suppliers and retail companies, the results showed that:

- There was a mediating relationship in the application of the IoT between SLM and OP, that is, the application of the IoT to SLM influenced and mediated OP. The mediating effect of the IoT application occurred with the aid of decision making (Galegale et al., 2016), proactivity (Hopkins \& Hawking, 2018), resource interconnectivity (Presser \& Gluhak, 2009; Porter \& Heppelmann, 2015; Tu, 2018), automation (Hopkins \& Hawking, 2018), dynamism (Galegale et al., 2016), generation of information to clients (Zhang et al., 2013) and elimination of errors (Porter \& Heppelmann, 2015), thus, supporting the H4 hypothesis defined for this research.

- SLM had a positive effect on the OP. In other words, to achieve Performance, it is necessary to carry out the SLM. The SLM was performed based on the company's strategic planning (Ballou, 2006) and with systems for the integration of logistical activities (Macaulay et al., 2015). In addition, they performed distribution planning (Machline, 2011; Kazimírová et al., 2015), inspection (Macaulay et al., 2015) based on flexibility (Ting \& Liao, 2013; Hübl et al., 2013), discipline and discipline focused on the client (Ting \& Liao, 2013; Hübl et al., 2013; Bowersox et al., 2014), thus satisfying the $H 1$ hypothesis of this research.

- SLM had a positive effect on the application of the IoT. Structural models allowed us to conclude that the application of the IoT occurs due to the issues explored in the results of hypothesis 1 . The curious thing is that IoT was applied to obtain information about the processes, but not with the objective of leaving the process autonomous, contradicting Chu et al. (2013), Zhang et al. (2013), and Nassar and Horn (2014). However, the other variables confirmed the $\mathrm{H} 2$ hypothesis. 
- The application of the IoT had a positive effect on OP. The OP was benefited by the application of the IoT in its transportation and storage operations, especially when considering the indicators related to efficiency (Duong \& Paché, 2015), low complaints rate, low failure rate, quality, flexibility, speed, deadline meeting, demand meeting, and productivity (Bowersox et al., 2014; Paiva et al., 2014), thus satisfying the H3 hypothesis of this research.

\section{CONCLUSION, IMPLICATIONS, AND SUGGESTIONS FOR FUTURE RESEARCH}

The quantitative research has guided the answer to the proposed research problem: "Does the application of the IoT mediate the relationship between SLM and OP?". The answer to this question was yes, the IoT plays a mediating but partial role in the relationship between SLM and OP. Partial mediation suggested that the application of the IoT can reduce the effect of SLM in OP, but that is not able to counter this effect. In addition, by including revenues in the model, it is possible to see that it is able to reduce the significance of the t-statistic from 3.17 to 2.96 of the impact of the application of the IoT on OP in $6.62 \%[((3.17-2.96) / 3.17)=0,0662]$ and to increase the significance of the t-statistic from 4.29 to 4.53 of the impact of SLM in OP in $5.59 \%$, $[(4.53-4.29) / 4.29)=0.0559]$, in other words, the application of the IoT was more sensitive to the control variable than the SLM.

Regarding management practices, transportation, warehousing, and retail executives can draw some insights from this study. The main insight is that the application of the IoT positively impacts OLP. Implementing the IoT by enabling proactive decisions, interconnecting resources, automating, streamlining, generating customer information, and eliminating errors can provide better efficiency, reduce complaint rates and process failures, improve quality, flexibility, and productivity of storage and transport services, as well as assisting in meeting deadlines for delivering, however unusual they may be.

The bibliometric review allowed us to conclude that studies on the application of technologies inherent to industry 4.0 are still scarce in the business area, so this study may drive the development of research on this topic, especially on the application in logistics activities. For researchers wishing to study the application of the IoT, this research contributed to the development of a measurement plan, as well as to explore practical applications of the IoT in Logistics and demonstrate its effect on the relationship between SLM and OP. 


\subsection{Suggestions for future research}

To continue research in this area, it is suggested to increase the sample size in order to enhance the generalization power of the correlations. It is also proposed to perform longitudinal research to verify the behavior of the proposed model over time. Also, it is suggested to compare the results obtained with other companies from different economic segments and to carry out studies in model companies to seek to answer the "why" they adopted the IoT, thus verifying whether the expectations were reached if there were a financial return and other approaches.

\section{O PAPEL DA IOT NA RELAÇÃO ENTRE GESTÃO ESTRATÉGICA DA LOGÍSTICA E DESEMPENHO OPERACIONAL}

\section{RESUMO}

Objetivo: Tendo como pano de fundo os custos de transação e o arcabouço teórico da gestão estratégica da logística (GEL), do desempenho operacional (DO) e da internet das coisas (IoT), o objetivo deste estudo é verificar se há efeito mediador da IoT na relação entre GEL e OP.

Originalidade/valor: A análise bibliométrica indicou que os estudos sobre a IoT direcionados à área de negócios ainda são escassos, portanto há uma perspectiva de expansão da fronteira do conhecimento no campo da administração. Este artigo busca mostrar se a IoT tem influência mediadora na relação entre GEL e DO, além de destacar as variáveis significativas de cada constructo. Este estudo pode ajudar gerentes de negócios a identificar os benefícios da adoção da IoT. Quanto aos pesquisadores, podem utilizar a escala de mensuração para pesquisas futuras.

Design/metodologia/abordagem: Para isso, realizou-se uma pesquisa quantitativa com coleta de dados por meio de questionário semiestruturado com uma amostra de 76 empresas. Os dados foram tratados com uso da estatística descritiva e da estatística multivariada com a técnica de modelagem em equações estruturais. Antes da aplicação da técnica de modelagem em equações estruturais, os dados foram submetidos a testes de validade convergente e discriminante. 
Resultados: A IoT desempenha um papel mediador, mas parcial, no relacionamento entre GEL e DO. A implementação da IoT melhora a eficiência com a tomada de decisões proativas e interconexão de recursos. Sua aplicação busca automatizar, simplificar, controlar remotamente e gerar informações sobre o cliente e eliminar erros.

\section{PALAVRAS-CHAVE}

Gestão estratégica da logística. Internet das coisas. Desempenho operacional. Modelagem em equações estruturais. Escala de mensuração.

\section{REFERENCES}

Abersfelder, S., Bogner, E., Heyder, A., \& Franke, J. (2016). Application and validation of an existing industry 4.0 guideline for the development of specific recommendations for implementation. Advanced Materials Research, 1140, 465-472. doi:10.4028/www.scientific.net/AMR.1140.465

Ashton, K. (2009). That "Internet of Things" thing. RFID Journal. Recuperado de http://www.rfidjournal.com/articles/view? 4986

Ballou, R. H. (2006). Gerenciamento da cadeia de suprimentos/logística empresarial (5a ed.). Porto Alegre: Bookman.

Baron, R. M., \& Kenny, D. A. (1986). The moderator-mediator variable distinction in social psychological research: Conceptual, strategic and statistical considerations. Journal of Personality and Social Psychology, 51 (6), 1173-1182. doi:10.1037//0022-3514.51.6.1173

Bido, D. S., Godoy, A. S., Araujo, B. F. V. B., \& Louback, J. C. (2010). A articulação entre as aprendizagens individual, grupal e organizacional: Um estudo no ambiente industrial. Revista de Administração Mackenzie, 11 (2), 68-95. doi:10.1590/S1678-69712010000200004

Bititci, U. S. (2015). Managing business performance: The science and the art. Chichester, UK: John Wiley \& Sons. doi:10.1002/9781119166542.ch11

Bowersox, D. J., Bowersox, J. C., Closs, J., \& Cooper, M. B. (2014). Gestão logística da cadeia de suprimentos (4a ed.). Porto Alegre: AMGH. 
Brous, P., Janssen, M., \& Herder, P. (2019). The dual effects of the Internet of Things (IoT): A systematic review of the benefits and risks of IoT adoption by organizations. International Journal of Information Management, 51, 1-17. doi:10.1016/j.ijinfomgt.2019.05.008

Chin, W. W. (1998). Issues and opinion on structural equation modeling. MIS Quarterly, 22(1), vii-xvi.

Chu, L., Chen, X., \& Dang, S. (2013). Design and implementation of supply chain integrated system based on Internet of Things. Applied Mechanics and Materials, 433-435, 2395-2400. doi:10.4028/www.scientific.net/AMM. 433-435.2395

Cohen, J. (1988). Statistical power analysis for the behavioral sciences (2nd ed.). New York: Lawrence Erlbaum Associates. doi:10.1016/C2013-0-10517-X

Creswell, J. W. (2010). Projeto de pesquisa: Métodos qualitativo, quantitativo e misto (3a ed.). (M. F. Lopes, Trad.). Porto Alegre: Artmed. doi:10.26512/ les.v13i1.11610

Duong, H., \& Paché, G. (2015). Intégration informationnelle et relationnelle au sein de la dyade chargeur/PSL: Une exploration dans le contexte vietnamien. Actes de la 5éme Conférence ATLAS-AFMI, Hanoï, Vietnam.

Evdokimov, I. V., Alalwan, A. R. J., Tsarev, R. Y., Yamskikh, T. N., Tsareva, O. A., \& Pupkov, A. N. (2019). A cost estimation approach for IoT projects. Journal of Physics, 1176, 1-8. doi:10.1088/1742-6596/1176/4/042083

Fornell, C., \& Larcker, D. F. (1981). Evaluating structural equation models with unobservable variables and measurement error. Journal of Marketing Research, 18(1), 39-50. doi:10.1177/002224378101800104

Galegale, G. P., Silva, C. B. H., Siqueira, E., \& Souza, C. A. (2016). Internet das coisas aplicada a negócios: Um estudo bibliométrico. Revista de Gestão da Tecnologia e Sistemas de Informação, 13(1), 423-438. doi:10.4301/s180717752016000300004

Gartner Group (2017). Gartner says 8.4 billion connected “Things” will be in use in 2017, up 31 percent from 2016. Recuperado de https://www.gartner. $\mathrm{com} /$ newsroom/id/3598917

Giudice, M. D. (2016). Discovering the Internet of Things (IoT) within the business process management: A literature review on technological revitalization. Business Process Management Journal, 22 (2), 263-270. doi:10.11 08/BPMJ-12-2015-0173

Gomes, F. P. (1985). Curso de estatística experimental. São Paulo: Piracicaba: Nobel. 
Hair, J. F., Anderson, R. E., Babin, B. J., Black, W. C., \& Tatham, R. L. (2005). Análise multivariada de dados (5a ed.). (A. S. Sant'Anna, Trad.). Porto Alegre: Bookman.

Hair, J. F., Hult, G. T. M., Ringle, C. M., \& Sarstedt, M. (2014). A Primer on Partial Least Squares Structural Equation Modeling (PLS-SEM). Los Angeles: Sage.

Hopkins, J., \& Hawking, P. (2018). Big Data Analytics and IoT in logistics: A case study. International Journal of Logistics Management, 29(2), 575-591. doi:10.1108/IJLM-05-2017-0109

Hübl, A., Altendorfer, K., \& Jodlbauer, H. (2013). Influence of dispatching rules on average production lead time for multi-stage production systems. International Journal of Production Economics, 144, 479-484. doi:10.1016/j. ijpe.2013.03.020

Iacobucci, D., Deng, X., \& Saldanha, N. (2007). A mediation on mediation: Evidence that structural equation models perform better than regression. Journal of Consumer Psychological, 7(2), 140-154. doi:10.1016/S10577408(07)70020-7

Kazimírová, J., Busa, M., \& Puskás, E. (2015). Structure of corporate logistics costs. The International Journal of Transport \& Logistics, 15, 1-11.

Macaulay, J., Buckalew, L., \& Chung, G. (2015). Internet of Things in logistics. Troisdor: DHL Trend Research, Cisco Consulting Services. Recuperado de http://www.dhl.com/content/dam/Local_Images/g0/New_aboutus/ innovation/DHLTrendReport_Internet_of_things.pdf

Machline, C. (2011). Cinco décadas de logística empresarial e administração da cadeia de suprimentos no Brasil. Revista de Administração de Empresas, 51 (3), 227-231. doi:10.1590/S0034-75902011000300003

Marques, F. (2017). O Brasil da internet das coisas. Pesquisa Fapesp (ed. 259). Recuperado de http://revistapesquisa.fapesp.br/2017/09/21/o-brasil-dainternet-das-coisas/

Marquez, F. P. G., Nieto, M. R. M., \& Pardo, I. P. G. (2015). Competitiveness based on logistic management: A real case study. Annals of Operations Research, 233(1), 157-169. doi:10.1007/s10479-013-1508-z

Martello, L. L., \& Dandaro, F. (2015). Planejamento e controle de estoque nas organizações. Revista Gestão Industrial, 11 (2), 170-185. doi:10.3895/gi. v11n2.2733

Nassar, V., \& Horn, V. M. L. (2014). A internet das coisas com as tecnologias RFID e NFC. $11^{\circ}$ Congresso Brasileiro de Pesquisa e Desenvolvimento em Design, São Paulo, SP, Brasil. doi:10.5151/designpro-ped-00043 
Paiva, E. L., Finger, A. B., \& Teixeira, R. (2014). Novas tecnologias e desempenho operacional: Um estudo internacional comparativo. Revista Administração de Empresas, 54(2), 126-140. doi:10.1590/S0034-759020140202

Patel, K. K., \& Patel, S. M. (2016). Internet of Things - IoT: Definition, characteristics, architecture, enabling technologies, application \& future challenges. International Journal of Engineering Science and Computing, 6(5), 6122-6131.

Pathak, P. B. (2016). Internet of Things: A look at paradigm shifting applications and challenges. International Journal of Advanced Research in Computer Science, 7(2), 49-51. doi:10.26483/ijarcs.v7i2.2630

Porter, M. E., \& Heppelmann, J. E. (2015). How smart, connected products are transforming companies. Harvard Business Review, 96-112. Recuperado de https://hbr.org/2015/10/how-smart-connected-products-are-transformingcompanies

Prasad, G., \& Singh, Y. N. (2015). Logistic management: A case study with special reference on physical infrastructure. Anusandhanika - Research Journal of Commerce \& Business Management, 7(1), 100-104.

Presser, M., \& Gluhak, A. (2009) The Internet of Things: Connecting the real world with the digital world. EURESCOM mess@ge - The Magazine for Telecom Insiders, 2.

Ringle, C. M., Bido, D., \& Silva, D. (2014). Modelagem de equações estruturais com utilização do SmartPLS. Revista Brasileira de Marketing, 13(2), 56-73. doi:10.5585/remark.v13i2.2717

Rodrigues, A., Lynch, D., \& Stank, T. (2004). Linking strategy, structure, process, and performance in integrated logistics. Journal of Business Logistics, 25(2), 65-94. doi:10.1002/j.2158-1592.2004.tb00182.x

Saurin, G., Raupp, M., \& Trento, F. C. (2014). Gestão de estoques: Controle da matéria-prima em uma empresa produtora de aditivos para alimentos. Revista Thêma et Scientia, 4(2), 8-21.

Schwab, K. (2016). A quarta revolução industrial (D. M. Miranda, Trad.). São Paulo: Edipro.

Ting, C.-K., \& Liao, X.-L. (2013). The selective pickup and delivery problem: Formulation and a memetic algorithm. International Journal of Production Economics, 141, 199-211. doi:10.1016/j.ijpe.2012.06.009

Tu, M. (2018). An exploratory study of Internet of Things (IoT) adoption intention in logistics and supply chain management. Department of Transportation Science, 29(1), 131-151. doi:10.1108/IJLM-11-2016-0274 
Williamson, O. E. (2007). Transaction cost economics: An introduction. Economics Discussion Papers, 1(2007-3), 1-32. doi:10.2139/ssrn.1691869

Yu, X., \& Bai, Y. (2013). Internet of Things and its application in intelligent logistics. Applied Mechanics and Materials, 241-244, 3201-3204. doi:10.40 28/www.scientific.net/AMM.241-244.3201

Zhang, F., He, H., \& Xiao, W. (2013). Application analysis of Internet of Things on the management of supply chain and intelligent logistics. Applied Mechanics and Materials, 411-414, 2655-2661. doi:10.4028/www.scientific. net/AMM.411-414.2655

\section{AUTHOR NOTES}

Yan M. Lopes, master from the Graduate Program in Business Administration (PPGA), Mackenzie Presbyterian University (UPM); Roberto G. Moori, Ph.D. from the Production Engineering Department, University of São Paulo (USP).

Yan M. Lopes is now a Ph.D. student at the PPGA-UPM; Roberto G. Moori is now a full professor at the Center for Social and Applied Sciences (CCSA) of UPM

Correspondence concerning this article should be addressed to Yan M. Lopes, Rua da Consolação, 896, Prédio 45, Consolação, São Paulo, São Paulo, Brazil, CEP 01302-907.

E-mail: yanlopes152@gmail.com

\section{EDITORIAL BOARD}

Editor-in-chief

Gilberto Perez

Associated editor

Maurício Reinert do Nascimento

Technical support

Vitória Batista Santos Silva

\author{
EDITORIAL PRODUCTION \\ Publishing coordination \\ Jéssica Dametta \\ Language editor \\ Daniel de Almeida Leão \\ Layout designer \\ Emap \\ Graphic designer \\ Libro
}

